\title{
Drug Related Corruption
}

\section{Author: Mark Adams}

Faculty Mentor: Emile Sahliyeh, Ph.D., Department of International Studies, College of Arts and Sciences, University of North Texas

Department and College Affiliation: Department of International Studies, College of Arts and Sciences, University of North Texas 


\section{Bio:}

Mark Adams is a senior majoring in International Studies at the University of North Texas. He places a high premium on scholarship which is reflected in his academic endeavors. He is an active member of the Honors College and has consistently made the Dean's and President's Lists. Mark has traveled the world, from India where he visited Tibetan refugee camps helping with microfinance projects to Athens, Greece, where he worked at the United States Embassy for a semester, travelling throughout the country giving presentations. Mark's work with the State Department was featured in a European wide inter-embassy magazine. Mark also has traveled to central Mexico where he helped build the only church for an impoverished village. While studying at North Central Texas College he served as the Treasurer and President of Scholarship for his schools' Phi Theta Kappa chapter, the international honor society. Upon graduation, Mark plans on attending graduate school to further his studies in Political Science. 


\begin{abstract}
:
This paper explores the relationship between the global drug trade and the corruption of government officials. The drug trade's corrupting effects are evident in major drug-cultivating countries, drug-transit countries and drug-consumer countries. I examine these three stages of the drug trade and how corruption operates at each stage. This study includes an analysis of corruption in Columbia, Mexico and the United States. The paper is organized into 5 sections. Section 1 is a brief history of the international drug prohibition regime. Section 2 defines the problem. Section 3 describes cases of corruption by country. Section 4 details U.S. policies implemented to prevent corruption. Section 5 concludes analyzing the potential for success of implementing U.S. anti-corruption policies in drug-producing and drug-transit countries.
\end{abstract}




\section{Introduction}

The purpose of this study is to explore the relationship between the global drug trade and corruption of government officials. It also explores government policies and other factors that may have a positive effect on deterring drug related corruption. The United Nations International Narcotics Board ascertained that corruption is a primary barrier to enforcing drug prohibition throughout the world (INCB 2010, 1-13). Drug related corruption is far reaching, often found at all levels of government, from local police to members of the president's cabinet and even at times the president him/herself (Cheurprakobkit 2000, 21) (Rempel 2011, 147-155) (Stout 2012, 36-37).

The drug trade's corrupting effects are evident in major drug-cultivating countries, i.e. Colombia, Peru, and in Afghanistan (Bowden 2001) (Gutcher 2011) (Glaze 2007, 6) (Richani 2007, 411) (Robinson 2003, 2) (Jelsma, Kramer and Rivier 2006, 15) (Schweich 2008, 3) (Tickner 2003, 74, 76) (Walser, "Columbia and Obama” 2010, 11). Corruption is also evident in major drug-transit countries, i.e. Mexico and Ecuador and Venezuela (Booth, Fainaru 2009) (Freeman 2011, 67) (Grayson 2010, 181) (Noriss 2009, 2) (Stout 2012) (Walser, “Mexico” 2008, 6, 10) (Walser, "U.S. Strategy" 2010, 4). Corruption is less evident in major drug-consumer countries, like the United States and the United Kingdom (“The Failed State Index” 2011) (“Corruption Perceptions Index” 2011).

The United States is the largest contributor of foreign aid in the world for drug control programs (Alesina, Dollar 2000, 36) (UNODC). For 2012 the U.S. Department of State earmarked $\$ 1.75$ billion in aid for 'narcotic control' programs including strengthening law enforcement institutions around the world that are weak and corrupt (Department of State Budget 
2011, 98). Other countries also contribute to drug control programs through the United Nations Office on Drugs and Crime, notable Japan and Britain (UNODC). Unfortunately the amount of U.S. and multilateral aid pales in comparison to revenue generated by drug related crimes, estimated to be between $\$ 300$ to $\$ 500$ billion annually or $8 \%$ of global trade (Greenfield and Reutuer 2001, 160) (White 2002, 975-976) (World Drug Report 1997, 124). Aid for narcotic control needs to go to programs that are effective. A primary goal of this thesis is to assist other researchers and policy makers in judging what anti-narcotic programs are effective.

There is little research from the political science community on the international drug trade. One reason for this is that criminals try very hard to keep their crimes a secret. It is important for researchers to examine this illicit trade because it grows in size year after year and its effects of corrupting, de-legitimizing and de-stabilizing governments are too great to ignore (Reuter and Greenfield 2000) (White 2002) (World Drug Report 2010).

\section{Rise in Transnational Crime}

Throughout the Cold war years, the United States' primary goal was to contain the Soviet Union (Hook and Spanier 2010, 37-44) (Kennan 1947). For almost half a century the United States turned a blind eye to transnational crime, as evident with the Iran-Contra scandal and the U.S. support for Noriega. The criminal activities of Noriega, allowing drug trafficking through Panama, were 'overlooked' considering he was an American ally in the Cold War (Hough 2008, 229-236) (Bagley 2011, 170). The United States supported right wing rebel groups while the Soviet Union funded leftist rebel groups throughout the world (Perdomo 2007, 3,11) (Siegel 2008, 2) (Steinberg 2000, 262). 
When the Cold War ended many groups and states lost their super power sponsor. Some turned to lucrative transnational crime for funding, i.e. the illegal arms trade, the drug trade, piracy and trafficking of women (Hough 2008, 229-236) (Keen 1998) (Ross 2004, 349). This period saw a dramatic increase in transnational crime. At the same time governments began noticing the destabilizing effects that organized crime had on the state; in particular the drug trade (INCB 2010, 1-13) (NSDD 1986, 3, 6) (Parliament of Canada 2012, 34) (United Nations $1988,10)$. New terms were added to the political lexicon to describe these global villains, 'narco-guerillas' and 'narco-terrorist' (Spector 1998) (Stepanova 2011).

In 1989, the U.S. invaded Panama and ousted the drug trafficking ruler Manuel Noriega. In the 1990's the United States became intimately involved in the assassination of Drug Kingpin Pablo Escobar in Colombia (Bowden 2001). In 1998 the Clinton administration gave a $\$ 1.3$ billion Aid package to Colombia to assist in their war with narco-guerillas. This made Colombia the third largest recipient of U.S. Military Aid (Chomsky 2001). After September $11^{\text {th }}$ the Bush Administration made a commitment to combat poverty and to strengthen states by increasing U.S. foreign aid by $50 \%$; seeing the national security threats posed by failed states like Afghanistan, the largest producer of opium in the world (Radelet 2012, 104) (Tarnoff 2005, 3) (World Drug Report 2010, 31, 37, 39).

The end of the Cold War saw the beginning of the rise of transnational crime. As interstate wars decrease in their occurrence and crime that crosses states borders becomes more prevalent. It is important that government policies adapt to face this new human security threat. Before examining 'corruption specific' government policies I would like to briefly review both 
U.S. anti-drug and intergovernmental anti-drug policies that shape the drug prohibition regime we have today.

This study is organized into 5 sections. Section 1 is a brief history of the international drug prohibition regime and section 2 defines the problem. Section 3 describes cases of corruption by country. Section 4 details U.S. policies implemented to prevent corruption. Section 5 concludes analyzing the potential for success of implementing U.S. anti corruption policies in drug-producing and drug-transit countries.

\section{Section 1: Pre-Drug Prohibition}

Drug use is not a new phenomenon. People have sought to alter their state of consciousness by consuming drugs for thousands of years and had done so unrestricted by governments (Nadelmann 1990, 502). In the late $19^{\text {th }}$ century the Hill Tribe people migrated from China to the Golden Triangle region bringing with them the practice of using opium for recreation, social and medical purposes (Cheurprakobkit 2000, 19). Similarly immigrants from China brought opium to the state of Sinaloa in Mexico around the turn of the $20^{\text {th }}$ century, where its cultivation went unregulated for decades (Bucardo, Jesus, Brouwer, Rodriguez, Ramos, Perez, Patterson and Strathdee 2005, 281) (Astorga 1999). In the Middle East narcotics have been used legally for over 4,000 years (Robins 2011, 32). An example of how important opium use was in Afyon, Turkey the city was named after the plant, literally meaning opium (Robins 2011, 32). In Yemen, Quat a stimulant and mild hallucinogen, has been cultivated for decades and widely used daily. Indeed $80 \%$ of agricultural land is still devoted to growing the drug (Robins 2011, 33). In the United States drug use was also not banned by the government until the late $19^{\text {th }}$ century. Pressure from moral interest groups, large pharmaceutical interest groups and a racial fear of 
immigrants and drug use all cumulated to the passing of the first state anti-drug laws on the west coast in 1875 (Nadelmann 1990, 506).

\section{Significant U.S. Anti-Drug Laws}

The United States has been the leading advocate for global anti-drug laws. The structuring of the global drug prohibition regime can be traced back to U.S. domestic laws that were exported throughout the world.

In 1970 the U.S. congress passed the Bank Secrecy Act in response to drug traffickers using U.S. banks to launder money. This required U.S. banks to report cash transactions of more than $\$ 10,000$ a day and individuals had to claim cash in excess of $\$ 5,000$ when crossing borders. This policy of identifying the source of bank deposits spread to other countries and soon became an international norm (Andelman 1994, 96-96).

In 1986 president Ronal Regan issued a National Security Decision Directive that made drug enforcement a national security priority (Andelman 1994, 96) (NSDD 1986). This is the first U.S. government policy that links the drug trade to destabilizing states and the corrupting of government officials. That same year the federal Anti Drug Law was passed giving the president the power to determine whether or not major drug-producing and drug-transit countries were complying with anti-drug regulation. If a country loses their certification, then their U.S. aid will be cut in half and the United States will vote against all bilateral aid to the country (Bagley 2011, 169, 180) (Room, Robin and Paglia 1999, 31). In 1986, the U.S. Congress placed economic sanctions on Bolivia for not making enough progress in their coca eradication efforts (Bagley 
2011, 165). This law has been a source of tension on U.S./Mexican and Colombian relations (Freeman 2011, 66).

It is worthwhile to explore if the U.S. export of its anti-drug regulations have been successful. Stringent anti-drug laws may be effective in the U.S., with competent judicial and police institutions and where large scale drug production is not an issue. However if the U.S. exports policies of stringent drug prohibition to a country that has for centuries cultivated drugs, and 'coerces' that country's already fragile judicial and police institutions to implement these laws, then the U.S. might be setting these countries up for failure, quite literally (state failure) (Parliament of Canada 2012, 37).

\section{Building an International Prohibition Regime}

The international prohibition regime was established by three United Nations (U.N.) treaties. They are, the Single Convention, the Traffic in Narcotic Drugs and Psychotropic Substances and the Convention against Illicit Traffic in Narcotic Drugs and Psychotropic Substances. When examining these treaties, the influence from the Global North (the United States and Western Europe) is evident. In the Single Convention of 1961, a consolidation of 9 treaties, much of the responsibility is placed on the cultivating-nations, i.e. the coca producing countries in the Andean region of South America, the opium producing countries in Southeast Asia and cannabis producing counties in Southern Africa (Parliament of Canada 2000, 19-20). The Global North lacks the climate and the biogeography to permit the cultivation of coca and poppy in abundant quantities (Parliament of Canada 2000, 9). This has compelled policy makers from the Global North to view the cultivation of drugs as a cultivating-countries' problem. If the cultivating-countries could control the export of drugs from their country then the Global North 
would not have to fight domestic drug wars. The war on drugs over the past 40 years has primarily been a war on the supply side of drugs. All of the cultivating-countries are developing countries who lack the military and economic force to fulfill the obligations required of them from the U.N. treaties and U.S. policies mentioned (Bagley 1988, 173) (Parliament of Canada 2000, 37).

The U.N. Single Convention was the first treaty to prohibit a drug internationally. The convention does not allow for the legalization of any drug prohibited in the treaty (Krajewski 2008, 4). Countries like the Netherlands and Mexico, both signatures of the Single Convention, have de-criminalized in some cases and de-penalized classes of drugs, but they never legalized a drug prohibited in the treaty (Krajewski 2008, 2-3, 5). The World Health Organization (WHO) has the authority to decide if a drug has the capability of causing an addiction. Also the WHO was given the task of classifying what category the drug would be placed, ranging from category I-IV (Room, Robin and Paglia 1999, 306). Many of the classifications are dated, placing cannabis in the same category as heroin (Krajewski 2008, 3). The United States is a founding member and a major contributor to the WHO earmarking \$106 million to the organization in 2012 (Department of State Budget 2011, 40). This gives the U.S. considerable influence in the organization, and possibly predisposes the WHO to biases.

The U.N.'s 1971 Traffic in Narcotic Drugs and Psychotropic Substances extends drug control to synthetic psychotropic substances i.e. pharmaceutical drugs. The convention also criminalizes money laundering activates (Andelman 1994, 104). There was tremendous resistance from the Global North, the main producers of pharmaceutical drugs, against drug control that would threaten a major economic market for them (Parliament of Canada 2000, 20, 
25) (Room, Robin and Paglia 1999, 308). In the end multinational pharmaceutical industries had overwhelming influence on the Psychotropic Convention. The chief author of the convention's preparatory draft was Arthur Lande, representing the U.S. Pharmaceutical Manufacturer's Association (Parliament of Canada 2000, 25)

The U.N. 1988 Convention against Illicit Traffic in Narcotic Drugs and Psychotropic Substances is designed to combat trafficking. The convention promotes international cooperation on seizing assets of traffickers, preventing money laundering and the trafficking of pre-curser chemicals across national borders (Parliament of Canada 2000, 33). The U.S. 1999 Foreign Narcotics Kingpin Designation Act is very similar to the U.N. convention mentioned. It gives the U.S. government authority to confiscate assets from drug traffickers within the United States and it also established criminal penalties for doing business with known drug traffickers (Department of Treasury 1999, 1).

\section{Drug Prohibition Failure}

On the domestic front, the U.S. war on drugs has cost over $\$ 1$ trillion dollars and more than 30 million people have been arrested since 1982 (Alexander 2010, 25). Of the more than 1.8 million people arrested a year in the U.S., $40 \%$ of them are for possession of cannabis (Nadelmann 2007, 30).The U.S. ranks first in the world in per capita incarceration. With 5\% of the world's population the U.S. imprisons $25 \%$ of the world's prisoners (Nadelmann 2007, 26). Still the U.S. consumes over half of the world's illicit drugs (Robins 2011, 41).

A global analysis of the drug prohibition regime tells a similar story. Only $0.2 \%$ of global drug profits are confiscated annually (White 2002, 975-976). After 40 years of fighting an ardent 
war on drugs, that in Mexico alone has cost over 47,000 lives, the street price of cocaine and heroin are at an all time low (Cave 2012) (Freedman 2011, 71). During the rare times that enforcement does drive up the prices of drugs, this only encourages addicts to commit more crime to pay for their addiction (White 2002, 979). Production and consumption has remained the same over the past 10 years. Producers are becoming more efficient and drugs are more potent (Nadelmann 2007, 24).

The results of arresting drug kingpins and the dismantling of cartels are inconclusive. One would think the logical result of these actions would be a disruption in the drug trade. Instead there is a balloon effect. When pressure is placed on one cartel, then another cartel becomes more powerful (White 2002, 976). This was seen in Colombia in the late 90's. Both the U.S. and Colombian government put pressure on the Medellin Cartel killing their leader Pablo Escobar. Instead of deterring drug trafficking, this strengthened the Colombian Cali cartel and the rebel group the Revolutionary Armed Forces of Colombia (FARC), who became more involved in drug trafficking (Bowden 2001) (Rempel 2011). This also strengthened the Mexican Cartels who began to take over territory in Colombia that the Medellin Cartel previously controlled.

\section{Section 2: Defining Corruption}

Corruption can take many forms and varies in its degree of severity. The possible participants involved in corruption are: law enforcement, the military, central and local government and the judicial branch of government. Drug corruption has decaying effects on institutions. Where corruption is present within an institution, i.e. police institution, it is generally found throughout the institution. It is institutionalized and taught to new members. The 
old adage applies: it's not just a bad apple, it's the entire barrel. Below, Figure 1 lists four types of corruption, defining them and listing those government individuals that are involved in the corruption.

\section{Figure 1: Types of corruption}

\begin{tabular}{|l|l|l|}
\hline Type & Characteristics & $\begin{array}{l}\text { Government actor who } \\
\text { participate in the racket }\end{array}$ \\
\hline $\begin{array}{l}\text { Protection or non- } \\
\text { enforcement of the } \\
\text { law }\end{array}$ & $\begin{array}{l}\text { Selling protection to a criminal } \\
\text { to prevent enforcement of the } \\
\text { law. I.e. this may be a onetime } \\
\text { bribe to overlook a shipment of } \\
\text { drugs or a weekly bribe to allow } \\
\text { a criminal organization to } \\
\text { operate. }\end{array}$ & $\begin{array}{l}\text { Law Enforcement }^{(1)} \\
\text { Military, Gov }^{(2)}\end{array}$ \\
\hline $\begin{array}{l}\text { Exonerating } \\
\text { charges }\end{array}$ & $\begin{array}{l}\text { This can range from police } \\
\text { tampering with evidence to } \\
\text { judges 'letting off' criminals. }\end{array}$ & Law Enforcement, Judicial $^{(4)}$ \\
\hline Extralegal violence & $\begin{array}{l}\text { Drug executions, physical abuse } \\
\text { for coercive purposes. }\end{array}$ & Law Enforcement, Military \\
\hline $\begin{array}{l}\text { Taking over } \\
\text { criminal activity }\end{array}$ & $\begin{array}{l}\text { This is where the government } \\
\text { employee literally runs an aspect } \\
\text { of the drug trade, i.e. selling } \\
\text { cocaine, trafficking cocaine etc. }\end{array}$ & Law Enforcement \\
\hline
\end{tabular}

Notes

1. Law Enforcement, to include: police, customs, border patrol and coast guard.

2. Gov, to include: the executive branch or president's cabinet, federal ministers and the legislative branch, governors and municipal public officials.

4. Judicial, to include: both municipal and federal judges.

*These types of corruption were identified by analyzing cases of corruption found in Colombia, Mexico and the United States all three of which have a federal system of government.

All of the types of corruption listed in Figure 1 are a reaction to a strong government. If the government is weak and cannot enforce the law throughout its territory than drug growers, traffickers and dealers can operate freely. These groups have to bribe government officials because they cannot circumvent them. Drug Trafficking Organizations (DTOs) invest ample supply of money each year to pay off officials. In Mexico alone it is estimated that DTOs spends as much as $\$ 500$ million a year on bribery. This was in 1998 and this figure has undoubtedly has 
increased (Andreas 1998 162). This is \$100 million more than the U.S. gave to Mexico in the Mérida initiative to assist in the war on the DTOs.

\section{Section 3: Country Specific Cases of Corruption}

Drug related corruption is found in every country that DTOs operate. From drugproducing countries, where corruption is found at all levels of the government, from top officials to custom officers. In drug-transit countries, corruption is generally found at the top levels of government and in law enforcement (Nadelmann 1988, 7). In major drug-consumer countries drug related corruption is generally only found at the law enforcement level, these cases are few in number (Punch, 2000) (Dombrink 1988).

An analysis of Transparency International's 2012 Corruption Perception Index data set, which ranks 183 countries from one to nine with one being the most corrupt, found that the mean corruption rank of drug-producing countries is 2.5 . Out of the seven drug-producing countries two ranked in the top five most corrupt countries; the range, 1.5 to 3.4 . The mean corruption rank of drug-transit countries is 3.2 ; the range, 1.8 to 7.3 .

Below I examine the three stages of the drug trade and how corruption operates at each stage from the drug-cultivating country to the drug-transit country to the drug-consumer country. I do this by examining corruption in Columbia, Mexico and the United States.

\section{Drug Corruption in Colombia}

Colombia is a major drug-producing country as identified by the United States code $(2003,618)$ as defined under the $490(\mathrm{~h})$ of the Foreign Assistance Act of 1961 (FAA), where Congress has designated 'Drug-Producing' and 'Drug-Transit' countries (National Archives and 
Records Administration 2162). There are 20 countries that produce and/or transit drugs (“Presidential Memorandum” 2010).

Corruption in drug-producing countries is found at all levels of the government, from top to bottom (Nadelmann 1988, 7). The Columbian state is penetrated by members of DTOs. To realize how entrenched the Colombian state is in corruption, one only needs to look back to the early 1990's. Pablo Escobar, a drug kingpin and leader of the Medellin Cartel, campaigned and was elected to the Colombian Parliament (Bowden 2001) (Lynch 2007, 2). Escobar later lobbied with 'plomo o plata' (silver or lead) to get Colombia's extradition laws changed to prevent his extradition to the United States. The largest bribe Escobar offered was to pay off Colombia's foreign debt if he was pardoned of all drug trafficking charges (Bowden 2001). This bribe was turned down and Escobar served jail time in a private prison that he designed, built and was free to come and go from (Bowden 2001). Escobar served a year of his sentence before escaping, after he was told that he would be transferred to a real prison. A year later Escobar was killed by a special anti-drug unit trained and assisted by U.S. intelligence-agencies.

Corruption in Colombia did not die with Pablo Escobar. Escobar's rival DTO, the Cali Cartel, also paid millions of dollars in bribes to government officials including a presidential candidate (Rempel 2011). After the death of Escobar the guerilla group, the Revolutionary Armed Forces of Colombia (FARC), and the paramilitary group the United Self-Defense Forces of Colombia (AUC) grew larger and became more involved in drug trafficking. It is estimated that $35 \%$ of the elected congress in Colombia supports the AUC (Richani 2007, 411). Also in 2010 a major investigation began of 87 members of congress, 15 governors and 35 mayors for their illegal ties to the paramilitaries (Walser "Columbia" 2010,11). One of the more disturbing 
incidents of police corruption were the Trujillo massacres; where between 1988 and 1991 over 100 assassinations were carried out by government forces in collaboration with DTOs (Tickner 2003, 76). This is the "extra legal violence" type of corruption mentioned in Figure 1.

\section{Drug Corruption in Mexico}

The Mexican government, at the local and the federal levels, had a long history of coopering with DTO's. This dates back to the creation of the Institutional Revolutionary Party (PRI), who ruled Mexico for over 70 years (Walser "U.S. Strategy" 2008, 4-5). For 70 years the Mexican government along with the police had served as mediators between the DTOs. The government divided the country up into plazas or areas of control that they sold to DTOs (Freeman 2011, 65) (Walser "Mexico" 2008, 6). This had two results. First, having government enforced areas to operate, prevented turf wars among the DTOs. Second, it enabled the creation of a few very large DTOs. The smaller DTOs could not afford to buy and control plazas. This system of corruption was disrupted in 2000 with the election of Felipe Fox, a member of the National Action Party (PAN). Six years later Fox's predecessor Felipe Calderon, also a PAN member, began the war on drugs in Mexico. He persuaded congress to increase military spending by $24 \%$ or 2,500 million a year. He followed this by deploying 25,000 troops to hot spots throughout the country. This led to the arrest of over 22,000 criminals (Freedman 2011, 69). These forces have remained deployed along with further increased troop deployment by President Calderon.

\section{Mexico Law Enforcement}


Mexico’s law enforcement institutions are totally corrupt. In 1998 Mexico’s Attorney General's Office estimated that 70 to 80 percent of the federal judicial police were corrupt (Andrea 1998, 164). This is why Mexico's President, Felipe Calderon has used the military so extensively to fight a war on the DTOs; he cannot rely on the police. A 1995 study found that there were around 900 armed criminal groups throughout the country, $50 \%$ of which were made up of former police officers (Andreas 1998, 162). This is the "taking over criminal activates" type of corruption as listed in Figure 1. The most prominent type of corruption found in Mexico's law enforcement institutions, especially within the federal judicial police, is selling protection (Punch 2000, 303) (Nadelmann 1988). It is very common for the police (both local and federal) to collect a 'corruption tax' from criminal organizations in exchange for protection from the law. The groups who refuse to pay this tax are arrested and harassed by the police. These selective, 'show arrests' create an illusion that the police are doing their job.

A 1988 study found that customs officials are the most corrupt government officials in drug-transit countries (Nadelmann 7). This seems evident in Mexico. With the election of Vincent Fox in 2000, 45 of the 47 Customs inspectors along the American-Mexican border were fired or transferred. In just a month 150 trucks were apprehended carrying narcotics. This is a remarkable increase from the 38 that were apprehended the following year.

\section{The Military and the Problem with Special Drug Units}

The militaries in Latin America that are not involved in drug enforcement generally are not corrupt. It is the special drug units found in both Colombia and Mexico that tend to be notoriously corrupt (Nadelmann 1988, 7). One such group in Mexico is the Airmobile Special Forces Groups (GAFES). Created in 1996, thousands of GAFES were trained by an assortment 
of foreign specialist from the United States, France and Israel (Grayson 2010, 183-184)

(Freedman 2011, 67). The GAFES primary function was to serve as a special drug unit. Defected members of GAFES went on to server as sicarios (assassins) for the Gulf Cartel. Later they formed the Zetas, a paramilitary-cartel. The Zetas are the most deadly of the Mexican DTOs. Their membership ranges from 200-300 members (Grayson 2010, 189). Their weaponry is military grade, including 50-caliber rifles, ground-to-air missiles, bazookas, dynamite, grenades, helicopters and even self-constructed tanks (Grayson 2010, 185).

The Zetas are an example of blowback from a specially trained military drug unit. This problem stems from corruption being institutionalized. In Mexico, positions in the special drug units are sometimes auctioned off because it is known that these positions have the potential for earning the most in bribes. This institutionalized corruption poses a serious problem for U.S. Drug Enforcement Agents (DEA) operating in other countries. Since the DEA generally has few options of non-corrupt officials to work with, they have found that the best approach is to create specialized anti-drug units within the country they are working in (Nadelmann 1988, 11). But

still in every country that the DEA and U.S. State Department have created such units, corruption reached to the highest levels of government. It is difficult to shield these special units from corruption under these circumstances (Nadelmann 1988, 13). Also, sometimes the successful works of these special units are undermined by the corrupt judicial system in the country.

\section{Past Drug Corruption in the United States}

Drug related corruption in the United States that has occurred within law enforcement institutions has been infrequent, although all the types of corruption listed in Figure 1 have 
occurred in the U.S. I will discuss four cases of drug related corruption below, two within the New York Police Department (NYPD) and two within the Miami Police Department (MPD).

In the 1970's New York detective Frank Serpico made numerous reports to his superiors that corruption was widespread within the NYPD. After being ignored Serpico 'blew the whistle' about the corruption to the New York Times. This publicity spurred the creation of the Knapp Commission to look into the corruption (Punch 2000, 307) (Dombrink 1988, 201). The commission found that institutionalized-widespread corruption was found within the NYPD (Dombrink 1988, 201). The corrupt practices ranged from turning a blind eye to some criminal organizations to other criminals being released of all charges. Twenty years later the Mollen Commission found that some New York police officers not only sold protection to drug dealers but also had become users and sometimes dealers themselves (Punch 2000, 208).

In 1987, 27 Miami police officers were indicted for a racket where informants would lead them to million-dollar drug busts, which they would steal, letting the dealer go free (Dombrink 1988, 206). Also in 1988 three Miami police officers were charged with first degree murder for participating in a drug execution (Dombrink 1988, 207).

The above mentioned cases all occurred over 20 years ago. Aside from the NYPD cases, police corruption in the U.S. generally is a case of one bad apple and not a failure of the institution. It would be misleading to think that there is no longer corruption within the U.S. law enforcement institutions. But after searching news-databases it is difficult to find recent cases of drug related corruption within the United States. What has the United States government done different in protecting its institutions (Law Enforcement, Judicial and Political) from corruption? In Section 4, I will explore these questions. 


\section{Section 4: Preventing Corruption, the U.S. Model}

Police corruption in the U.S. has occurred in rare instances. Generally when corruption has occurred it has been a case of a few bad apples, such as the 1987 Miami case. The only case where it seems corruption was institutionalized was within the NYPD before 1970 and later reemerging as the drug trade grew with increased globalization in the mid 1980's. Two police commissions, the Knapp and Mollen Commission, were formed to investigate the corruption within the NYPD and to make policy changes to prevent future corruption. The policy-changes made after the commissions appear to have transformed a once corrupt institution into a police department that is now free of corruption. A search of news-databases turns up no future cases of corruption within the NYPD. This affirms the effectiveness of the two commissions. Bellow I will discuss the commissions' policy changes implemented and analyze the potential for success of implementing these policies in drug-producing and transit-countries.

In the 1970's when police detective Frank Serpico informed his superiors that much of the NYPD was corrupt, he was ignored. It was not until Serpico 'blew the whistle' to the media that attention was given to the corruption issue within the NYPD (Punch 2000, 307) (Dombrink 1988, 201). This highlights how important an independent media is to preventing government corruption in a society. Another example of the influence that the media can have on deterring corruption occurred in the Bahamas in the 1980's. The U.S. government acquired information revealing that the Prime Minister, Sir Lynden O. Pindling, and some of his cabinet members were receiving bribes from DTOs. After diplomacy failed the U.S. government leaked the incrementing information to the U.S. media. This created such a reaction with the public in the Bahamas that Prime Minister Pindling was pressured into appointing a commissioner to investigate the corruption charges (Nadelmann 1988, 17). Also in January of 2011 U.S. 
diplomatic cables were released by WikiLeaks detailing corruption within the ruling family of Tunisia. This was enough to push the Tunisian people over the edge starting a revolution that eventually led to the overthrow of President Ben Ali (Dickinson 2011) (Sanina 2011). The media holds public servants accountable by keeping the public informed.

The Knapp Commission implemented four major changes within the NYPD to prevent future corruption.

- First, an accountability system was established where police commanders were held responsibility for their subordinates' actions. To implement this policy a new police commissioner was appointed, Patrick Murphy, who told his 180 commanders he would hold them personally responsible for their subordinates actions (Dombrink 1988, 218) (Grayson 2000, 307).

- Second, integrity test were carried out by special undercover units. They tempted officers in the street to commit crimes and/or to accept bribes. The police unit commanders were unaware of when and where an integrity test would occur.

- Third, a robust Internal Affairs was created that became a kind of feared Gestapo (Grayson 307-308).

- Fourth, citizens who offered bribes were arrested.

These policies were successful at reducing corruption to an "almost minimal level" (Dombrink 1988, 218). It was not until 20 years later that some drug related corruption began to re-appear the corruption was not extensive in the police ranks. It was limited to a few officers. The Mullen Commission found that Internal Affairs had become relaxed over the years and this allowed the 
few cases of corruption to occur. Internal Affairs was re-vamped after the Commission's findings. These policies have had a positive effect on preventing corruption within the NYPD. Since the 1970s the NYPD has been almost entirely free of corruption, with the exception of a few individuals. This is quite an accomplishment keeping in mind that the NYPD is the largest police department within the United States.

\section{Conclusion}

Can the anti-corruption policies that were implemented within the NYPD in the 1970s be successfully implemented in drug-producing and drug-transit countries? In drug-producing countries corruption is generally found at all levels of the government from the top officials down to the customs agents (Nadelmann 1988, 7). In this case before police reform can be successfully implemented, reform higher up in the government would have to take place. As discussed in Section 4 an independent media can be an effective catalyst for political reform. In drug-transit countries corruption is generally more limited to lower levels of government. This may include police, customs agents and local government officials (i.e. governors, mayors, city officials). In these cases it would more feasible to implement police reform. Bear in mind that in this study the United States, Mexico and Colombia were used as case studies. But there are many other drug-consuming, drug-transit and drug-producing countries all that differ. They may share some common characteristics in how drug corruption occurs within their borders but it would be imprudent to over generalize. Rather policy makers should adapt effective strategies to the specific situation they are dealing with. For an example before 2000 Mexico had been ruled for 71 years by the PRI party and drug corruption reached the highest levels of government. After 
the 2000 election and subsequent reform corruption is limited to mostly state and local government officials, with the exception of the federal police. So a policy that might be effective in 2001 would have been completely ineffective two years earlier under the PRI party. The lessons we have learned from the cases studied in this research are good starting places. The model describing government corruption, Figure 1, will not fit every country but it should be used as guide in assisting future researchers and policy makers.

Since the Cold War's end liberalism's greatest threat is transnational crime. This might be terrorism, trafficking in nuclear, biological or chemical weapons or the drug trade fuelling corruption and leading to the degradation of governments. The wars on drugs and terrorism will not be won on the battlefield. The victory will begin with policy changes. Or wars will be lost due to path dependency. It is essential to change path, or policy, when misjudgments have been made rather than to continue a failed policy and be limited by past bad decisions. 


\section{Bibliography}

Alesina, Alberto, and David Dollar. "Who Gives Foreign Aid to Whom and Why?" Journal of Economic Growth 5.1 (2000): 33-63. Academic Search Complete. Web. 28 Dec. 2011.

Alesina, Alberto, and Beatrice Weder. "Do Corrupt Governments Receive Less Foreign Aid?" Working Paper 7108: 1-42. Natioanl Bureau of Economic Research. May 1999. Web. 15 Dec. 2011. <http://www.nber.org/>.

Alexander, Michelle. "Obama's Drug War." The Nation 27 Dec. 2011: 25-27. Print.

Andelman, David A. "The Drug Money Maze." Foreign Affairs 1994: 94-108. Web. 20 Dec. 2011.

Andreas, Peter, and Ethan Avram. Nadelmann. Policing the Globe: Criminalization and Crime Control in International Relations. Oxford: Oxford UP, 2006. Print.

Andreas, Peter. "The Political Economy of Narco-Corruption in Mexico." Current History (1998): 160-65. JSTOR. Web. 21 Jan. 2012

Astorga Almanza, Luis Alejandro. "El siglo de las drogas". Mexico City: Planeta. 1996

Bagley, Brucee M. "The New Hundred Years War? US National Security and the War on Drugs in Latin America." Journal of Interamerican Studies and World Affairs 30.1 (1988): 161-82. JSTOR. Web. 15 Dec. 2011.

Bowden, Mark. Killing Pablo: The Hunt for the World's Greatest Outlaw. New York: Atlantic Monthly, 2001. Print.

Bucardo, Jesus, Kimberly C. Brouwer, Carlos M. Rodriguez, Rebeca Ramos, Miguel Fraga, Saida G. Perez, Thomas L. Patterson, and Steffanie A. Strathdee. "Historical Trends in the Production and Consumption of Illicit Drugs in Mexico: Implications for the Prevention of Blood Borne Infections." Drug Alcohol Depend 3rd ser. 79.1 (2005): 281-93. NIH Public Access. Web. 21 Dec. 2011.

Cave, Damien. "Mexico Updates Death Toll in Drug War to 47,515, but Critics Dispute the Data." The 
New York Times 11 Jan. 2012. Print.

Cheurprakobkit, Sutham. "The Drug Situation in Thailand: The Role of Government and the Police." Drug and Alcohol Review 19.1 (2000): 17-26. EBSCO. Web. 15 Dec. 2011.

Chomsky, Noam. An American Addiction: Drugs, Guerillas, and Counterinsurgency in US Intervention in Colombia. Cambridge: AK, 2001. Audio.

Corruption Perceptions Index: Transparency International. Web. 11 Apr. 2012. <http://cpi.transparency.org/cpi2011/results/>.

Dickinson, Elizabeth. "The First WikiLeaks Revolution?" Foreign Policy. 13 Jan. 2011. Web. 20 Mar. 2012. Dombrink, John. "The Touchable: Vice and Police Corruption in the 1980's." Law and Contemporary Problems 51.1 (1988): 201-32. JSTOR. Web. 18 Jan. 2012.

Fainaru, Steve, and William Booth. "Widespread Oil Theft by Drug Traffickers Deals Major Blow to Mexico's Government." Washington Post: Breaking News, World, US, DC News \& Analysis. 13 Dec. 2009. Web. 25 Jan. 2012. <http://www.washingtonpost.com/wpdyn/content/article/2009/12/12/AR2009121202888.html>.

"Foreign Terrorist Organizations." U.S. Department of State. Web. 21 Jan. 2012. <http://www.state.gov/j/ct/rls/other/des/123085.htm>.

Freeman, Laurie. "A Tale of Two Countries: Drugs, Guns, Violoence and the US-Mexico Border." The Politics of Narcotic Drugs: A Survey. London: Routledge, 2011. 64-71. Print.

Gorman, D.M. "'War on Drugs" Continues In United States Under New Leadership." BMJ: British Medical Journal 307 (1993): 369-71. JSTOR. Web. 19 Jan. 2012.

Grayson, George W. Mexico: Narco-violence and a Failed State? New Brunswick, NJ: Transaction, 2010. Print.

Gutcher, Lianne. "Hamid Karzai's Brother Assassinated in Southern Afghanistan." The Guardian. 12 July 2011. Web. 05 Nov. 2011. <http://www.guardian.co.uk/world/2011/jul/12/hamid-karzaibrother-assassinated- afghanistan>. 
Hook, Steven W., and John W. Spanier. "From World War to Cold War." American Foreign Policy since World War II. 18th ed. Washington, D.C.: CQ, 2010. 37-44. Print.

Hough, Peter. Understanding Global Security. 2nd ed. New York: Routledge, 2008. Print.

Hufbauer, Gary C., Jeffrey J. Schott, Kimberly A. Elliot, and Barbara Oegg. "Economic Sanctions Reconsidered." Peterson Institue for International Economics. Web. 15 Dec. 2011. Jelsma, Martin, Tom Kramer, and Cristian Rivier. "Losing Ground Drug Control and War in Afghanistan." Drugs \& Conflict 15 (2006): 4-35.

Keen, David. "The Economic Functions of Violence in Civil Wars." Adelphi Paper 320. London: International Institute of Strategic Studies. 1998. Print.

Kennan, GF. "The Sources of Soviet Conduct." Foreign Affairs. 1947. Web. 20 Jan. 2012.

Krajewski, Krysztof. "How Flexiable Are UN Drug Conventions?" Information on Substance Use, Dependence, Harm Reduction, International \& National Drug Policy / DrugText. 25 Dec. 2010. Web. 16 Jan. 2012. <http://www.drugtext.org/pdf/Law-and-treaties/how-flexible-are-un-drugconventions.pdf>.

Kraska, Peter B., and Victor E. Kappeler. "Militarizing American Police: The Rise and Normalization of Paramilitary Units." University of California Press 44.1 (1997): 1-18. JSTOR. Web. 15 Dec. 2011. Levine, Harry G. "Global Drug Prohibition: Its Uses and Crises." International Journal of Drug Policy 14 (2003): 145-53. JSTOR.

Lynch, David. "Colombia Works to Escape Its past." USA Today [Virginia] 4 Oct. 2007: 2-3 Meernik, James, Eric L. Krueger, and Steven C. Poe. "Testing Models of U.S. Foreign Policy: Foreign Aid during and after the Cold War." Cambridge University Press 60.1 (1998): 63-85. JSTOR. Web. 15 Dec. 2011.

Nadelmann, Ethan A. "Drugs." Washington Post Sept. 2007, 162nd ed.: 24-26. JSTOR. Web. 1 Jan. 2012. Nadelmann, Ethan A. "Global Prohibition Regimes: The Evolution of Norms in International Society." International Organizations 44.4 (1990): 479-526. JSTOR. Web. 18 Dec. 2011. 
Nadelmann, Ethan A. "The DEA in Latin America: Dealing with Institutionalized Corruption." Journal of Interamerican Studies and World Affairs 29.4 (1988): 1-39. JSTOR. Web. 18 Jan. 2012.

National Archives and Records Administration. 2001. Public papers of the presidents of the United States, 2162.

Norris, Michele. "Colombia's FARC Rebels Maintin Effective Unit." National Public Radio 9 June 2009: 13. EBSCO. Web. 25 Jan. 2012.

"NSDD - National Security Decision Directives - Reagan Administration." 1986.

Federation of American Scientists. Web. 15 Jan. 2012.

<http://www.fas.org/irp/offdocs/nsdd/nsdd-221.htm>.

Perdomo, Jose. R. 2007. Colombia's Democratic Security and Defense Policy in the Demobilization of the Paramilitaries. Pennsylvania: U.S. Army War College.

Punch, Maurice. "Police Corruption and Its Prevention." European Journal on Criminal Policy and Research 8.3 (2000): 301-24. Academic Search Complete. Web. 1 Feb. 2012.

Radelet, Steven. "Bush and Foreign Aid." Foreign Affairs Oct. 2003: 104-08. Pro Quest. Web. 1 Jan. 2012.

Reid, Gary, Madonna L. Devaney, and Simon Baldwin. "Drug Production, Trafficking and Trade in Asia and Pacific Island Countries." Drug and Alcohol Review 25 (2006): 647-50. EBSCO. Web. 15 Dec. 2011.

Rempel, William C. At the Devil's Table: The Untold Story of the Insider Who Brought down the Cali Cartel. New York: Random House, 2011. Print.

"Report of the International Narcotics Control Board for 2010." INCB. Web. 16 Jan. 2012. <http://www.incb.org/incb/en/annual-report-2010.html>.

Reuter, Peter, and Victoria Greenfield. "Measuring Global Drug Markets." World Economics 2.4 (2001): 159-73. Academic Search Complete. Web. 2 Dec. 2011.

Richani, Nazih. 2007. “Caudillos and the Crisis of the Colombian state: Fragmented Sovereignty, the War 
System and the Privatization of Counterinsurgency in Colombia." Third World Quarterly, 28:403417.

Robins, Philip. "The Middle East and Illicit Drugs: A Forgotten Region." The Politics of Narcotic Drugs: A Survey. London: Routledge, 2011. 31-46. Print.

Robinson, Linda. "Terror Close To Home." U.S. News \& World Report 6 Oct. 2003. EBSCO. Web. 25 Jan. 2012.

Room, Robin, and Angela Paglia. "The International Drug Control System in the Post-Cold War Era. Managin Markets or Fighting a War?" Drug and Alcohol Review 18 (1999): 305-15. EBSCO. Web. 15 Dec. 2011.

Ross, Michael L. 2004. "What Do We Know about Natural Resources and Civil War?" Journal of Peace Research, 41:337-56.

Sanina, Mila. "WikiLeaks Cables Help Uncover What Made Tunisians Revolt." PBS News Hour. 25 Jan. 2011. Web. 20 Mar. 2012.

Schirmer, Jennifer. "The White Economy: Drugs, Poverty and Violent Conflict in Columbia." The Politics of Narcotic Drugs: A Survey. London: Routledge, 2011. 47-63. Print.

Schweich, Thomas. "Is Afghanistan a Narco-state?" International Herald Tribune 24 July 2008: 1-10. Discover Uzes. Http://consommacteurs.blogs.com/pg/files/karzai_drug_profiter.pdf. Web. 25 Jan. 2012. <http://consommacteurs.blogs.com/pg/files/karzai_drug_profiter.pdf>.

Siegel, Robert. "FARC Has Ability To Keep Fighting, Experts Say." National Public Radio 3 Apr. 2008. Academic Search Complete. Web. 25 Jan. 2012.

Spector, Bertram. I. 1998. "Deciding to negotiate with villains." Negotiation Journal, 14:43-59. Academic Search Complete. Web. 25 Jan. 2012.

Steinberg, Michael. K. 2000. "Generals, Guerrillas, Drugs, and Third World War-Making." Geographical Review, 90:260-267.

Stepanova, Ekaterina. "Beyond 'narcoterrorism': Illicit Drugs Business and Terrorist Tactics in Armed 
Conflcts." The Politics of Narcotic Drugs: A Survey. London: Routledge, 2011. 120-130. Print.

Stout, Robert J. "Do the United States and Mexico Really Want the Drug War To Succeed." Monthly Review. Jan. 2012. Web. 19 Jan. 2012.

Tarnoff, Curt, and Larry Nowels. "Foreign Aid: An Introductory Overview of U.S. Programs and Policy." Air University. 19 Jan. 2005. Web. 15 Jan. 2012. <http://www.au.af.mil/au/awc/awcgate/crs/98916.pdf>.

Tickner, Arlene. B. 2003. "Colombia and the United States: From Counternarcotics to Counterterrorism." Current History, 102:73-79.

"The Failed States Index 2011 Interactive Grid." The Fund for Peace. 2011. Web. 25 Jan. 2012. $<$ http://www.fundforpeace.org/global/?q=fsi-grid2011>.

"The History and Development of the Leading International Drug Control Conventions." Parliament of Canada. 2000. Web. 16 Dec. 2012. <http://www.parl.gc.ca/Content/SEN/Committee/371/ille/library/history-e.pdf>.

"United Nations Convention Against Illicit Traffic In Narcotic Drugs and Psychotropic Substances." United Nations Office on Drugs and Crime. 1988. Web. 24 Jan. 2012.

United Nations Drug Control Program. 1997. World Drug Report. Vienna, Austria United Nations Drug Control Program. 2010. World Drug Report. Vienna, Austria United Nations Office on Drugs and Crime. Web. 16 Feb. 2012. <http://www.unodc.org/unodc/en/donors/index.html>. United States Congress. House of Representatives. January 6, 2003. United States Code. Washington: Government Printing Office, 2:618.

United States. Department of Treasury. An Overview of the Foreign Narcotics Kingpin Designation Act. 1999. Web. 29 Jan. 2012.

United States. Federal Bureau of Investigations. A Model for Success in the Drug War. By Kelly J. Thomas. Federal Bureau of Investigations. Feb. 2011. Web. 19 Jan. 2012. 
United States. The White House. Office of the Press Secretary. Presidential Memorandum--Major Illicit Drug Transit or Major Illicit Drug Producing Countries. By Barack Obama. Washington, 2010.

Walser, Ray. 2008. "Mexico, Drug Cartels, and the Merida Initiative: A Fight We Cannot Afford to Lose." Backgrounder 2163: 1-12.

Walser, Ray. "U.S. Strategy Against Mexican Drug Cartels: Flawed and Uncertain." Backgrounder 2047 (2010): 1-15. Abstracts in Social Gerontology. Web. 15 Jan. 2012.

White, Tony. "Controlling and Policing Substance Use(rs)." SUBSTANCE USE \& MISUSE 37.8 (2002): 97383. Academic Search Complete. Web. 20 Dec. 2011. 